\title{
Gua-sha: application and therapeutic results in musculoskeletal pain situations. Systematic review
}

\author{
Gha-sha: aplicação e seus resultados terapêuticos em condições dolorosas musculoesqueléticas. \\ Revisão sistemática
}

Dérrick Patrick Artioli ${ }^{1}$, Gladson Ricardo Flor Bertolini ${ }^{2}$

DOI 10.5935/2595-0118.20190050

\section{ABSTRACT}

BACKGROUND AND OBJECTIVES: Gua-sha is a Traditional Chinese Medicine technique, which consists of scraping the skin with a smooth and rounded edges object until the appearance of petechiae. Used domestically in Asia, it is described as capable of promoting the improvement of several conditions (e. g. respiratory, digestive, fever, and insomnia), such as painful conditions. However, there is a shortage of systematic reviews in this respect in Western literature, so this study aimed to analyze the common use of Gua-sha and the methodological quality of the studies.

CONTENTS: The PEDro, Pubmed, Scielo and LILACS Databases were consulted, searching for clinical trials with the following keywords and Boolean index: Gua-sha AND pain; Scraping therapy AND pain (English, Portuguese and Spanish). Thirty-two articles were pre-selected, but only six met the inclusion criteria (clinical trial, pain as one of the evaluation criteria, musculoskeletal pain). The disorders reported were related to the spine, with a mostly superior response or similar to the control group, being investigated in the short term (7-21 days). The studies methodological quality were considered moderate according to the PEDro scale.

CONCLUSION: Gua-sha is a simple, inexpensive alternative with short-term effects for the treatment of conditions involving the spine and surrounding areas, such as a single intervention or in combination. Its practice is already well referenced but requires studies of high methodological quality and analysis of its effects also in the appendicular skeleton.

Keywords: Chinese Traditional Medicine, Pain, Physical therapy modalities, Physical therapy speciality, Rehabilitation.

Dérrick Patrick Artioli - Dhttps://orcid.org/0000-0003-3259-1725;

Gladson Ricardo Flor Bertolini - Dhttps://orcid.org/0000-0003-0565-2019.

1. Centro Universitário Lusíada, Santos, SP, Brasil.

2. Universidade Estadual do Oeste do Paraná, Cascavel, PR, Brasil

Submitted on October 29, 2018.

Accepted for publication on February 18, 2019.

Conflict of interests: none - Sponsoring sources: none.

Correspondence to:

Rua Universitária, 2069 - Jardim Universitário

85819-110 Cascavel, PR, Brasil.

E-mail: gladsonricardo@gmail.com

(C) Sociedade Brasileira para o Estudo da Dor

\section{RESUMO}

JUSTIFICATIVA E OBJETIVOS: Gua-sha é uma técnica da Medicina Tradicional Chinesa, que consiste em raspar a pele com objeto de bordas lisas e arredondadas até o surgimento de petéquias. De uso doméstico na Ásia, é descrita como capaz de promover a melhora de uma série de afecçôes (ex. respiratórias, digestivas, febre e insônia), como a de quadros dolorosos. Contudo, há escassez de revisôes sistemáticas a esse respeito na literatura ocidental, assim o objetivo deste estudo foi analisar a aplicação usual de Gua-sha e a qualidade metodológica dos estudos.

CONTEÚDO: Foram consultadas as bases de dados PEDro, Pubmed, Scielo e LILACS, buscando por ensaios clínicos com as seguintes palavras chaves e índice booleano: Gua-sha $A N D$ pain; Scraping therapy AND pain (inglês, português e espanhol). Foram pré-selecionados 32 artigos, mas apenas 6 atenderam os critérios de inclusão (ensaio clínico, dor como um dos critérios de avaliação, quadros álgicos musculoesqueléticos). Os distúrbios registrados foram relacionados à coluna vertebral, com resposta superior em sua maioria ou semelhante ao grupo controle, sendo investigados em curto prazo (7-21 dias). A qualidade metodológica aponta para estudos moderados de acordo com a escala PEDro.

CONCLUSÁO: Gua-sha é uma alternativa simples, de baixo custo, com efeitos estudados em curto prazo para tratamento de afecções envolvendo a coluna vertebral e áreas próximas, como intervenção única ou em associação. Sua prática já se encontra bem retratada, porém necessitando de estudos de alta qualidade metodológica e análise de seus efeitos também no esqueleto apendicular. Descritores: Dor, Fisioterapia, Medicina Tradicional Chinesa, Modalidades de fisioterapia, Reabilitação.

\section{INTRODUCTION}

Gua-sha, Scraping Therapy, Coining Therapy or Rubbing Technique are synonyms of a Traditional Chinese Medicine (TCM) technique, performed by "scraping" (Gua), unidirectional pressure on the patient's skin, usually lubricated, with an object of smooth and rounded edges (Chinese soup spoon, coin, buffalo horn slice, cow rib, sharped jade or metal lid or porcelain with rounded border (Figure 1), aiming to intentionally create therapeutic petechiae (Sha) which usually disappear within a few days (3-5 days).

In Asian communities, this technique is used as a homemade treatment, but, at first, it may be seen with suspicion by people unfamiliar to the technique, because of the transient marks left behind, and even mistaken for abuse ${ }^{1-3}$ (Figure 2). Its first description 


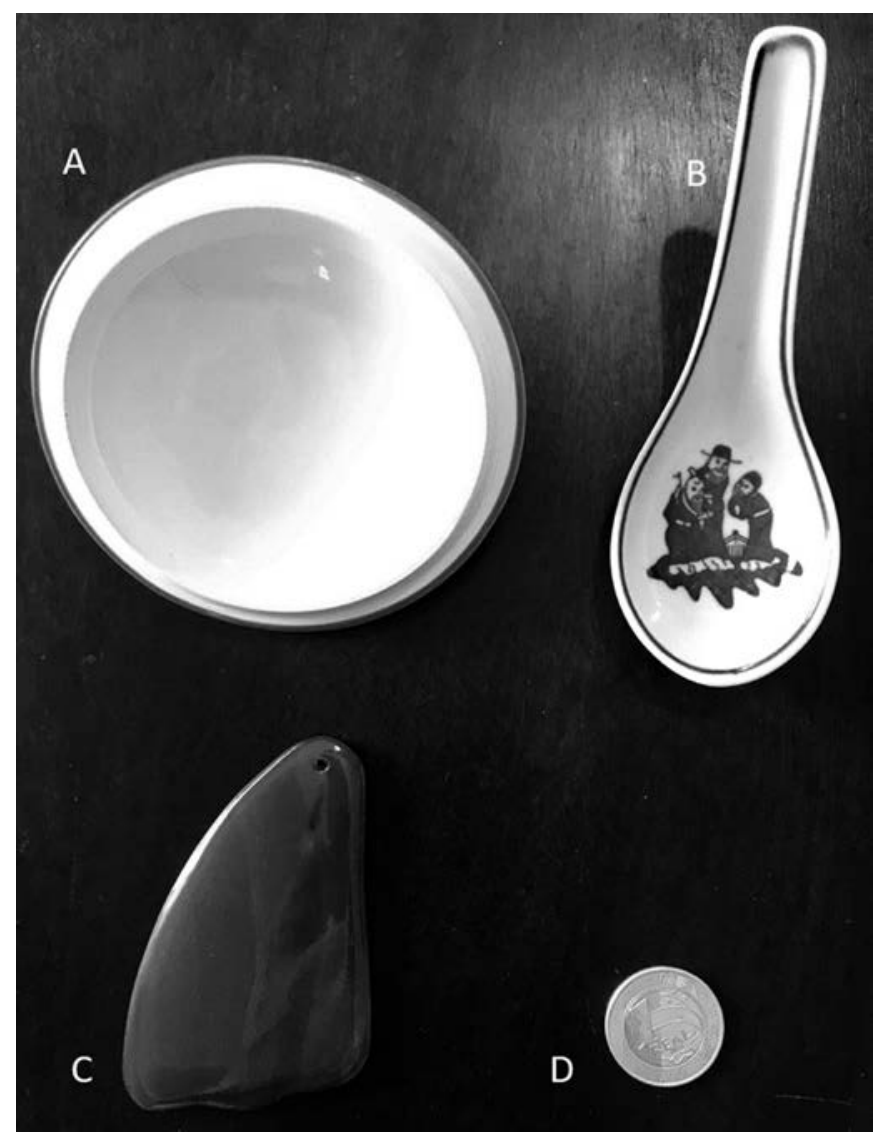

Figure 1. Tools for the Gua-sha Practice

$A=$ porcelain lid with rounded border; $B=$ Chinese soup spoon; $C=$ jade; $\mathrm{D}=$ coin.

Source: Authors' personal archives.

dates back to the end of the Han Dynasty (220 AD), and from the perspective of the TCM, it is able to remove impurities from injured tissues (e.g., muscles) from blood stagnation and facilitate the arrival of oxygenated "Fresh Blood "(Xue, Blood), promoting healing at the cellular level. Diseases of the upper respiratory tract, headache, fevers, insomnia, perimenopausal syndrome, and digestive disorders are within the indications for treatment with Gua-sha, as well as acute, chronic, and recurrent musculoskeletal pain $^{2,4}$. From a biomedical point of view, the resolution of painful conditions is justified by the increase of heme-oxygenase (HO1) and its anti-inflammatory and immunomodulatory effect ${ }^{4}$. In addition, three other possible mechanisms are described to support their effects on musculoskeletal pain: 1 - increase of the local microcirculation, reducing distal myalgia; 2 - stimulation of the serotonergic, noradrenergic and opioid systems; 3 - minimization of the direct effects of pain on the nociceptors, their surroundings, and the interconnections within the spinal cord ${ }^{4,5}$.

A previous systematic review of the literature was found, showing the effects of this technique in conditions of musculoskeletal pain. However, there is no mention of the practice of its application in the selected studies (only time and number of sessions), and the authors did not quantify the methodology of the stud$i^{5}$. These factors make possible a new analysis of the current literature, updating the studies, analyzing and complementing the information already published. Thus, the objectives of this

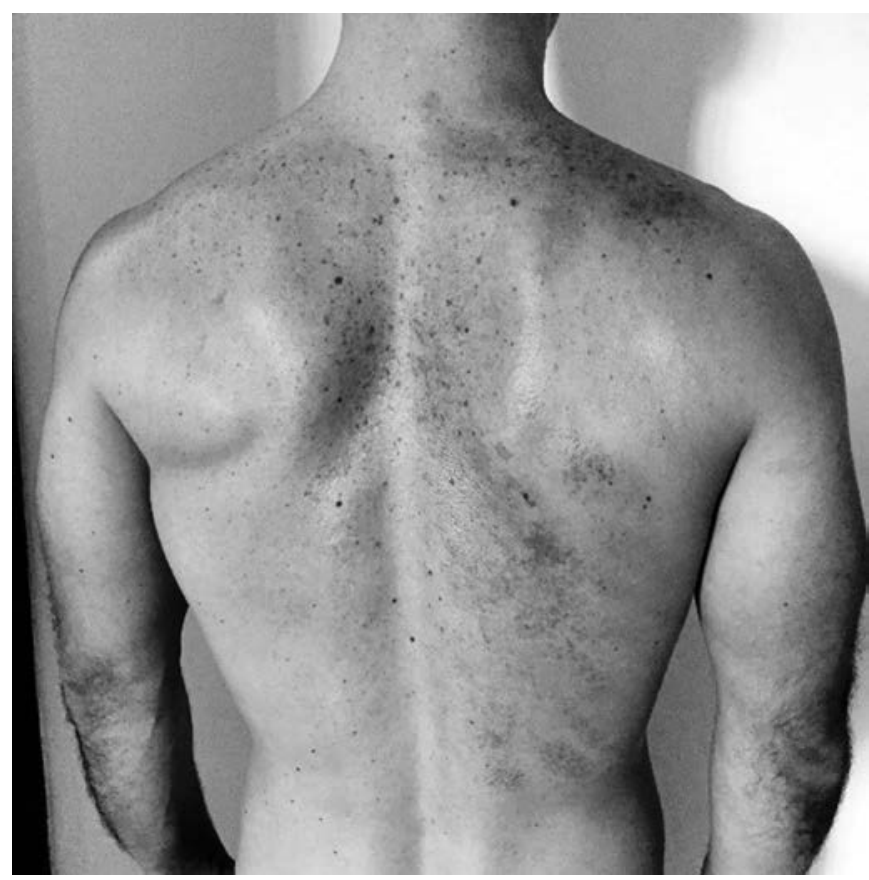

Figure 2. Ecchymosis after Gua-sha session on the right side of the back Source: Authors' personal archives.

study were: (1) to analyze the results of clinical trials with control group against painful pictures, using Gua-sha as an intervention; (2) to record the typical proposed application and (3) the methodological quality of the studies (PEDro scale) ${ }^{6}$.

\section{CONTENTS}

The databases PEDro, Pubmed, Scielo, and LILACS were consulted. The following keywords were used for the search: Gua-sha, scraping therapy, and pain (English, Portuguese, and Spanish). The Boolean index AND was used between the selected keyword and pain (Gua-sha AND pain; Scraping Therapy AND pain), directing to musculoskeletal pain and moving away from other variables (e.g., breast engorgement). These keywords should be present in the title or abstract topics of the article for inclusion. Also, "Clinical Trials" was one of the filters applied to eliminate other methodologies that did not mention comparative groups and needed to have pain as one of the analyzed variables. Other exclusion criteria were animal experiments, or when repeated in the databases, only one was selected. The studies that met the inclusion criteria were evaluated by the PEDro $^{6}$ scale for clinical trials, applied by two professionals with experience in musculoskeletal physiotherapy, without eliminating the research according to the score obtained, that is, only indicating the methodological quality of the study. Table 1 presents the quantitative data of the search performed.

The analyzed studies, for the most part, showed superior results with Gua-sha compared to the counter-intervention group (control). The practice generally occurs in the lubricated area, with stimulation in flow direction until new petechiae cannot be added, applied with tools such as the Chinese spoon, and the methodological quality of the studies is considered moderate. 
Table 1. Search and selection of studies in databases

\begin{tabular}{lcccc}
\hline Databases & Matches & Repeated & Excluded & Final \\
\hline PEDro & 10 & 1 & 4 & 5 \\
Pubmed & 20 & 8 & 11 & 1 \\
Scielo & 1 & - & 1 & 0 \\
LILACS & 1 & - & 1 & 0 \\
Total & 32 & 9 & 17 & 6 \\
\hline
\end{tabular}

Table 2 summarizes the results of the selected clinical trials presented in descending order, that is, the higher the score indicated by the PEDro scale ${ }^{6}$, the better the methodological quality of the study.

Conditions in or near the spine were the diagnoses that the studies turned to treat with Gua-sha, therefore, presenting no possible effects on the appendicular skeleton. Despite favorable results for this intervention, it should be pointed out that the

Table 2. Characteristics of the analyzed clinical trials

\begin{tabular}{|c|c|c|c|c|c|c|c|}
\hline Authors & Objectives & $\begin{array}{l}\text { Counter-inter- } \\
\text { vention }\end{array}$ & Population & Gua-sha & $\begin{array}{l}\text { Duration and } \\
\text { sessions }\end{array}$ & $\begin{array}{l}\text { PEDro } \\
\text { scale }\end{array}$ & Results \\
\hline $\begin{array}{l}\text { Braun } \\
\text { et al. }{ }^{7}\end{array}$ & $\begin{array}{l}\text { To assess the ef- } \\
\text { ficacy of Gua-sha } \\
\text { (IG) in chronic neck } \\
\text { pain (VAS: static } \\
\text { and in movement } \\
\text { pain; NDI: functio- } \\
\text { nal disability; SF- } \\
\text { 36: quality of life) }\end{array}$ & $\begin{array}{l}\text { CG: hot-water } \\
\text { bottle }\end{array}$ & $\begin{array}{lr}\text { Chronic } & \text { cer- } \\
\text { vicalgia; } 48 \\
\text { patients: } 24 \text { in } \\
\text { each group }\end{array}$ & $\begin{array}{l}\text { All cervical to high thoracic, } \\
\text { until additional petechiae } \\
\text { could not be added }\end{array}$ & $\begin{array}{l}\text { Single session, } \\
\text { i } \mathrm{m} \mathrm{m} \text { e d i a t e } \\
\text { reassessment } \\
\text { and follow-up } \\
\text { for the next } 7 \\
\text { days }\end{array}$ & 8 & $\begin{array}{l}\text { IG higher than } \\
C G(p<0.01)\end{array}$ \\
\hline $\begin{array}{l}\text { Yuen et } \\
\text { al. }{ }^{1}\end{array}$ & $\begin{array}{l}\text { Comparing the el- } \\
\text { derly with the pla- } \\
\text { cebo group (CG) in } \\
\text { chronic low back } \\
\text { pain (VAS, RMDQ, } \\
\text { SF-12, GDS, PSQI, } \\
\text { TFN- } \alpha \text {, and HO-1) }\end{array}$ & $\begin{array}{l}\text { CG: hot-water } \\
\text { bottle }\end{array}$ & $\begin{array}{l}\text { Chronic low } \\
\text { back pain; } 12 \\
\text { patients: all re- } \\
\text { ceived Gua-sha } \\
\text { (IG) or warm- } \\
\text {-bag (CG) with } \\
\text { a 28-day in- } \\
\text { terval between } \\
\text { evaluations }\end{array}$ & $\begin{array}{l}\text { T8-L5, about } 25-30 \mathrm{~cm} \text { in } \\
\text { length, until the appearan- } \\
\text { ce of petechiae }(8-12 \text { repe- } \\
\text { titions), } 15 \text { min. }\end{array}$ & $\begin{array}{l}\text { Single session, } \\
\text { re-evaluation } \\
\text { after } 24 \mathrm{~h} \text { and } \\
\text { in the } 7^{\text {th }} \text { day }\end{array}$ & 7 & $\begin{array}{l}\text { IG similar to } \\
\text { CG, with a ten- } \\
\text { dency towards } \\
\text { better results } \\
\text { in IG }\end{array}$ \\
\hline $\begin{array}{l}\text { Wang } \\
\text { et al. }\end{array}$ & $\begin{array}{l}\text { Influence of Gua- } \\
\text {-sha on channels } \\
\text { (IG) or acupuncture } \\
\text { points (CG1), with } \\
\text { or without petechiae } \\
\text { (CG2, CG3), as well } \\
\text { as conventional } \\
\text { acupuncture (CG4), } \\
\text { in low back muscle } \\
\text { tension, as for pain } \\
\text { (VAS) and functional } \\
\text { capacity (Oswestry) }\end{array}$ & $\begin{array}{l}\text { CG1: petechiae } \\
\text { at acupuncture } \\
\text { points; CG2: } \\
\text { no petechiae } \\
\text { in acupuncture } \\
\text { channels; } \\
\text { CG3: no pe- } \\
\text { techiae at } \\
\text { acupuncture } \\
\text { points } \\
\text { CG4: systemic } \\
\text { acupuncture }\end{array}$ & $\begin{array}{l}\text { Low back mus- } \\
\text { cle tension; } \\
210 \text { patients: } \\
42 \text { in each } \\
\text { group }\end{array}$ & $\begin{array}{l}\text { IG and CGC: bladder chan- } \\
\text { nel (TCM); } \\
\text { CG1, CG3, and CG4: points } \\
\text { B23 and B40 }\end{array}$ & $\begin{array}{l}\text { IG and CG1: } \\
4 \text { days; CG2, } \\
\text { CG3, and CG4: } \\
2 \text { days. The } \\
\text { five groups } \\
\text { were treated } 7 \\
\text { times. }\end{array}$ & 6 & $\begin{array}{l}\text { IG higher than } \\
C G(p<0.01)\end{array}$ \\
\hline $\begin{array}{l}\text { Lauche } \\
\text { et al. }{ }^{9}\end{array}$ & $\begin{array}{l}\text { To analyze the ef- } \\
\text { fects of Gha-sha on } \\
\text { VAS and pressure } \\
\text { pain (Algometer) on } \\
\text { neck pain and chro- } \\
\text { nic low back pain }\end{array}$ & CG: waiting list & $\begin{array}{l}\text { Neck pain and } \\
\text { chronic low } \\
\text { back pain; } 39 \\
\text { patients: IG } \\
\text { (20) and CG } \\
\text { (19) }\end{array}$ & $\begin{array}{l}\text { Cervical - C7-T12 longitu- } \\
\text { dinal to paravertebral; from } \\
\text { C7 horizontally to the shoul- } \\
\text { ders; C7-T12 following ribs; } \\
\text { C1-C7 longitudinally. } \\
\text { Low back - C7-L5 longi- } \\
\text { tudinal and then horizon- } \\
\text { tally; along with the gluteus } \\
\text { maximus; until petechiae } \\
\text { appear, about 10-15 min }\end{array}$ & $\begin{array}{l}\text { Single session, } \\
\text { i } \mathrm{m} \text { m e d i a t e } \\
\text { reassessment } \\
\text { and after } 7 \\
\text { days }\end{array}$ & 6 & $\begin{array}{l}\text { Pain intensity } \\
\text { IG higher than } \\
\text { control }(\mathrm{p}<0.05) \text {; } \\
\text { Pressure pain: } \\
\text { IG higher than } \\
\text { CG (neck pain, } \\
p<0.05) \text {; CG- } \\
\text { similar to IG } \\
\text { (low back pain, } \\
p>0.05)\end{array}$ \\
\hline $\begin{array}{l}\text { Xiao et } \\
\text { al. }^{10}\end{array}$ & $\begin{array}{l}\text { Compare Gua-sha } \\
\text { (IG) and acupunc- } \\
\text { ture (CG) in cervical } \\
\text { spondylosis (VAS) }\end{array}$ & $\begin{array}{l}\text { Systemic acu- } \\
\text { puncture }\end{array}$ & $\begin{array}{l}\text { Cervical spon- } \\
\text { dylosis; } 85 \text { pa- } \\
\text { tients: IG (44) } \\
\text { and CG (41) }\end{array}$ & $\begin{array}{l}\text { High cervical to the shoul- } \\
\text { ders }\end{array}$ & $\begin{array}{l}\text { IG: } 1 / \text { week, for } \\
3 \text { weeks } \\
\text { CG: } 1 / \text { day for } \\
15 \text { days }\end{array}$ & 5 & $\begin{array}{l}\text { Higher than CG } \\
\text { after the } 1^{\text {st }} \text { ses- } \\
\text { sion }(p<0.01) \text {; } \\
\text { similar to the fi- } \\
\text { nal one }(p>0.05)\end{array}$ \\
\hline Wang ${ }^{11}$ & $\begin{array}{l}\text { To investigate the } \\
\text { best method of } \\
\text { treatment for para- } \\
\text { vertebral pain }\end{array}$ & $\begin{array}{l}\text { Systemic acu- } \\
\text { puncture }\end{array}$ & $\begin{array}{l}\text { Paravertebral } \\
\text { pain; } 100 \text { pa- } \\
\text { tients: IG-50 } \\
\text { and CG-50 }\end{array}$ & $\begin{array}{l}\text { Applied to the association of } \\
\text { acupuncture and moxibus- } \\
\text { tion, in the painful points un- } \\
\text { der pressure, palpable ten- } \\
\text { sion bands and acupuncture } \\
\text { points B12, B13, ID12, ID13 } \\
\text { and extra point Jiafeng }\end{array}$ & - & 5 & $\begin{array}{l}\text { IG higher than } \\
\text { CG }(p<0.01)\end{array}$ \\
\hline
\end{tabular}

IG = intervention group; CG = counter-intervention group; VAS = visual analog scale; TCM = Traditional Chinese Medicine; NDI = Neck Disability Index; SF-36 = Short-form Health Survey-36; min = minutes; RMDQ = Roland-Morris Disability Questionnaire; SF-12 = Short-form Health Survey-12; GDS = Short-form Geriatric Depression Scale; PSQI = Pittsburgh Sleep Quality Index; TFN- $\alpha=$ tumoral factor alpha; HO-1 = Heme-oxygenase 1. 
two studies with a better methodological quality ${ }^{1,7}$ used only a hot water bottle as control, not being the gold standard for treatment and rarely used in the outpatient setting. That is, the comparison between the hot water bottle and Gua-sha may be valid in the East as a home treatment method, however, in the West, confrontation with other therapeutic modalities would bring greater clarification of its benefits ${ }^{12}$. The short period of analysis could also be pointed as a limiting factor, since the reassessment occurred immediately after the intervention or a follow-up of only a few days (7-21 days), not allowing longterm analysis ${ }^{1,7-10}$. However, it is claimed that its hypoalgesic effect can be noticed immediately or that it needs a few sessions to maintain it or provide resolution of the case, justifying the criteria used by the studies mentioned ${ }^{13}$. However, other treatment strategies frequently used and studied for years in the West are based on studies, such as those in Gua-sha ${ }^{1,7-11}$, that their results demonstrate short-term effects (e.g., Maitland and Mulligan ${ }^{14,15}$, Kinesio taping ${ }^{16,17}$ and transcutaneous electrical nerve stimulation (TENS) ${ }^{18}$. Thus, patients' long-term follow-up would provide more conclusive data not only on the treatment under review but also on other interventions that are commonly applied. Therefore, the superiority demonstrated by this method of treatment should not be undervalued ${ }^{7-11}$.

There was agreement among the authors regarding the fact that the Gua-sha site should be lubricated, to perform the technique until petechiae appear or stop when they could no longer occur, and that after application, the area should be covered and wait a few minutes before releasing the patient $t^{1,7,9,10}$. However, there was variability concerning the rationale of treatment lines, and three alternatives were described: the one initially described (Figure 2); in the bladder meridian of systemic acupuncture; in palpable tensile bands and points ${ }^{1,7-11}$. These practices had similar responses, making it impossible to say what stands out from the other. In 2012, Nielsen, Kligler and Koll ${ }^{13}$ brought up an issue that was little described and glimpsed by this literature review, proposing a "security protocol" to the use of Gua-sha. Once the blood and other potentially infectious materials can pass beyond the epidermis, leading to instrument contamination and exposure by pathogens. Therefore, they suggest the same hospital safety standards for Gua-sha practice: wearing gloves; disposable or sterile instruments (such as stainless steel and not made of horn or bone); not to reuse lubricant that has been applied. Despite the increase in superficial microperfusion and the mentioned risk, stable patients (international normalized ratio) who use anticoagulants can be treated with Gua-sha. However, it is worth mentioning that sunburn, rash, and skinned areas are contraindications to the use of this method, as well as patients with hemophilia, acquired immunodeficiency syndrome, and anemia (Figure 3) 7,13 .

The results can be explained by different analgesic theories, as previously mentioned. The physiological base is characterized by the vasodilatation or extravasation of superficial sanguineous vases, promoting an increase in the local cellular metabolism, absorption of inflammatory agents, reinforcement of the immunity (HO-1) and consequently the interruption of painful cycles ${ }^{7,8}$. Antinociceptive and anti-irritative effects also are

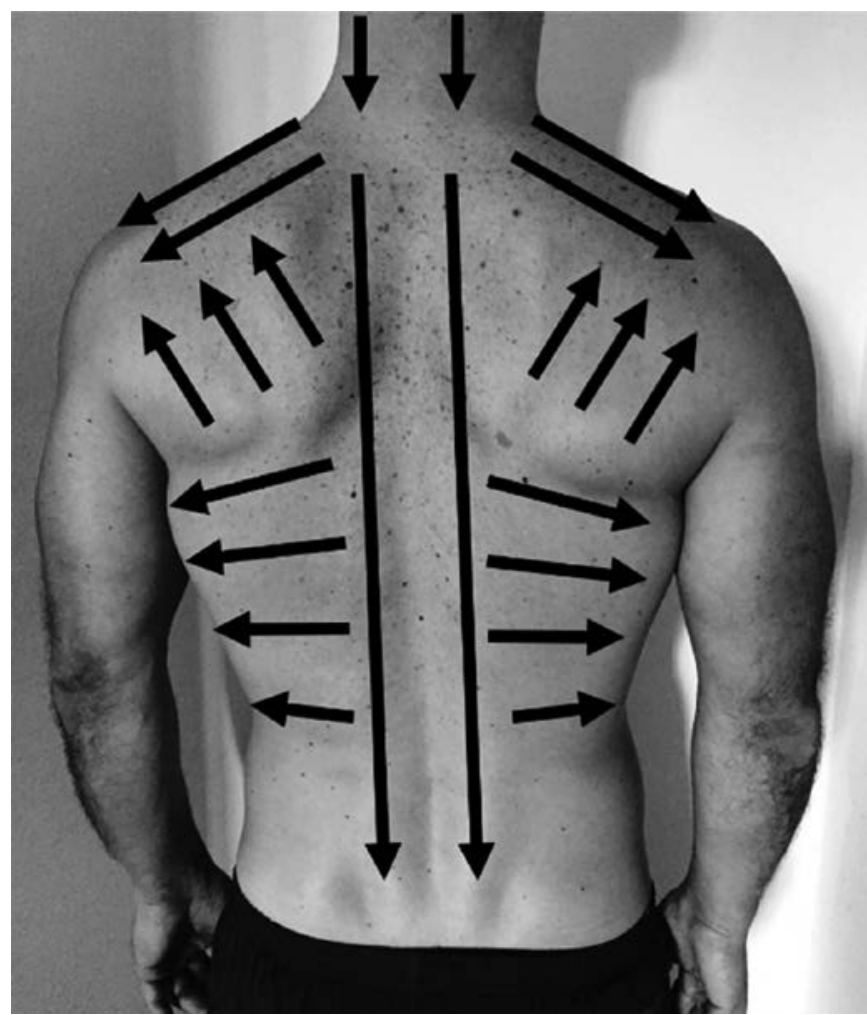

Figure 3. Gua-sha - application directions Source: Authors' personal archives.

described to justify its results, as the therapeutical stimulation of mechanoreceptors and nociceptors are involved in the inhibition mechanism of the painful signing conductivity in the spinal $\operatorname{cord}^{7,9}$. But by TCM, better results are obtained when its application is greater than $5 \mathrm{~cm}$ along a meridian of energy (e.g. systemic acupuncture bladder meridian) rather than just over acupuncture points, but combination of both could provide a more significant curative stimulus to the technique, these effects being linked to increased circulation of $\mathrm{Q} i$ (Chi, vital energy) and blood (Xue $)^{8}$.

Braun et al. ${ }^{7}$ stated that the options for conservative treatment in cases of chronic cervicalgia are limited and that Gua-sha could be an alternative for such cases, with fast reduction of pain and improvement of function. It is important to remember that not all people experiencing pain in this area will benefit from the technic. For example, those with neurological manifestations were excluded from the study, and there are few publications yet. Therefore, the diagnosis of mechanical cervical pain indicates improvement for the potential patients benefited by the technique ${ }^{7}$. One of the other studies under review also supports Gua-sha benefits in pain and overall health status, not only for chronic neck pain but also for chronic low back pain. With the premise of the neck area being more sensitive than the low back, authors justified the fact that Gua-sha provided a superior effect on pain at cervical pressure, but not at lower back pain ${ }^{9}$. The chronic lower back pain was also approached by Yuen et al. ${ }^{1}$. In comparison of Gua-sha with hot-water bottle, having only a trend of Gua-sha being superior, however, there 
was a reduction of the levels of tumour factor alpha (TNF- $\alpha$ ) and HO-1, both linked to the anti-inflammatory action, which lasted until the revaluation (day 7) and not evidenced in the control group (hot-water bottle). This gave rise to speculate an anti-inflammatory effect longer lasting by chronic pain, which would last for about seven days after a single intervention ${ }^{1,7,9}$, besides the possibility of reconciling Gua-sha with other practices, as demonstrated by Wang ${ }^{11}$, who obtained superior results together with moxibustion and systemic acupuncture instead of applying the latter alone.

Gua-sha has shown to be a simple and safe technique and, like other procedures in use, requires further studies to promote information on its long-term effects ${ }^{14-18}$. Whether alone or in combination with other modalities, not just TCM. Gua-sha still lacks more scientific support, despite already presenting moderate methodological quality in most of the analyzed studies, being an arduous task, since it is postulated that there may be a strong associated placebo effect. However, the authors denote the difficulty in having these groups since the technique leaves marks (ecchymosis), making their camouflage complex ${ }^{1,7,9}$.

\section{CONCLUSION}

Gua-sha has proved to be a relevant alternative for painful conditions involving the spine and the surroundings.

\section{REFERENCES}

1. Yuen JWM, Tsang WWN, Tse SHM, Loo WTY, Chan ST, Wong DLY, et al. The effects of Gua sha on symptoms and inflammatory biomarkers associated with chronic low back pain: a randomized active-controlled crossover pilot study in elderly. Complement Ther Med. 2017;32:25-32.

2. Marion T, Cao K, Roman J. Gua Sha, or coining therapy. JAMA Dermatol. 2018;154(7):788

3. Aprile A, Pomara C, Turillazzi E. Gua Sha a traditional Chinese healing technique that could mimick physical abuse: a potential issue with forensic implications. A case study. Forensic Sci Int. 2015;249:e19-20.

4. Ren Q, Yu X, Liao F, Chen X, Yan D, Nie H, et al. Effects of Gua Sha therapy on perimenopausal syndrome: a systematic review and meta-analysis of randomized controlled trials. Complement Ther Clin Pract. 2018;31:268-77.

5. Lee MS, Choi T, Kim JI, Choi SM. Using Guasha to treat musculoskeletal pain: a systematic review of controlled clinical trials. Chin Med. 2010;5:5.

6. Verhagen AP, de Vet HC, de Bie RA, Kessels AG, Boers M, Bouter LM, et al. The Delphi list: a criteria list for quality assessment of randomized clinical trials for conducting systematic reviews developed by Delphi consensus. J Clin Epidemiol. 1998;51(12):1235-41.

7. Braun M, Schwickert M, Nielsen A, Brunnhuber S, Dobos G, Musial F, et al. Effectiveness of traditional Chinese "gua-sha" therapy in patients with chronic neck pain: a randomized controlled trial. Pain Med. 2011;12(3):362-9.

8. Wang Y, Yang L, Yang J, Yang J, Liu Z, Chen F, et al. Curative effect of scraping therapies on lumbar muscle strain. J Tradit Chin Med. 2013;33(4):455-60.

9. Lauche R, Wübbeling K, Lüdtke R, Cramer H, Choi KE, Rampp T, et al. Randomized controlled pilot study: pain intensity and pressure pain thresholds in patients with neck and low back pain before and after traditional East Asian "gua sha" therapy. Am J Chin Med. 2012;40(5):905-17.

10. Xiao LM, Meng XP, Han ML, Yang JJ, Du SB, Zhang W, et al. [Controlled observation of clinical efficacy on cervical spondylosis of neck type treated with scraping and acupuncture]. Zhongguo Zhen Jiu. 2014;34(8):751-4. Chinese.

11. Wang LQ. [Observation on therapeutic effects of scraping therapy and warming acupuncture-moxibustion on 50 cases of fasciitis of back muscles]. Zhongguo Zhen Jiu. 2006;26(7):478-80. Chinese.

12. French SD, Cameron M, Walker BF, Reggars JW, Esterman AJ. Superficial heat or cold for low back pain. Cochrane Database Syst Rev. 2006;(1):CD004750.

13. Nielsen A, Kligler B, Koll BS. Safety protocols for gua sha (press-stroking) and baguan (cupping). Complement Ther Med. 2012;20(5):340-4

14. Moghaddam BA. Immediate effects of Maitland mobilization and Mulligan techniques on flexion and extension range of motion in patients with chronic nonspecific low back pain: a randomized pilot study. J Mod Rehabil. 2017;11(2):127-32.

15. Lee KS, Lee JH. Effect of Maitland mobilization in cervical and thoracic spine and therapeutic exercise on functional impairment in individuals with chronic neck pain. J Phys Ther Sci. 2017;29(3):531-5.

16. Ju S. The effects of short-term lumbar stability cross taping on muscle strength of trunk extension and lumbar pain level in patients with chronic back. J Phys Ther Sci. 2017;29(10):1757-9.

17. Halski T, Ptaszkowski K, Słupska L, Paprocka-Borowicz M, Dymarek R, Taradaj J, et al. Short-term effects of Kinesio taping and cross taping application in the treatment of latent upper trapezius trigger points: a prospective, single-blind, randomized, sham-controlled trial. Evid Based Complement Alternat Med. 2015;2015:191925.

18. Oosterhof J, Wilder-Smith OH, Oostendorp RA, Crul BJ. Different mechanisms for the short-term effects of real versus sham transcutaneous electrical nerve stimulation (TENS) in patients with chronic pain: a pilot study. J Pain Palliat Care Pharmacother. 2012;26(1):5-12. 